\title{
UJI AKTIVITAS ENZIM PROTEASE DARI ISOLAT Bacillus sp. ENDOFIT TANAMAN KELAPA SAWIT (Elaeis quinensis)
}

\author{
Atika Marnolia, Yuli Haryani, Fifi Puspita \\ Mahasiswa Program S1 Kimia FMIPA-Universitas Riau \\ Dosen Jurusan Kimia FMIPA-Universitas Riau \\ Dosen Jurusan Agroteknologi FAPERTA-Universitas Riau \\ Fakultas Matematika dan Ilmu Pengetahuan Alam Universitas Riau \\ Kampus Binawidya, Pekanbaru, 28293, Indonesia \\ E-mail: atikamarnolia@gmail.com
}

\section{ABSTRACT}

Proteolytic bacteria are able to hydrolyze proteins into amino acid and smaller peptides. The objective of this study to determine the abilty of three Bacillus sp. isolated from leaf (BD), root (BA), and stem (BP) of palm oil to produce protease. The proteolytic activity was determine based on the amount of tyrosin liberated in Unit/mL, while the specific activity was indicated by activity per unit weight of proteins. Protein concentration of enzymes extracts was determined by Lowry method. The results showed that all isolates were able to produce protease. Protease activity of Bacillus sp. BD, BA and BP was $(711,260 \pm 0,735) \times 10^{-3} \mathrm{U} / \mathrm{mL},(708,536 \pm 0,918) \times 10^{-3} \mathrm{U} / \mathrm{mL}$ and $(710,027 \pm$ $0,091) \times 10^{-3} \mathrm{U} / \mathrm{mL}$ in optimal production times of 24 hours, repectively.

Keywords: Bacillus sp, protease, protein, proteolytic bacteria.

\section{PENDAHULUAN}

Protease merupakan enzim yang berfungsi menghidrolisis ikatan peptida menjadi oligopeptida dan asam amino. Protease merupakan salah satu enzim industri yang paling penting dan memiliki nilai komersial mencapai $60 \%$ dari total penjualan enzim seluruh dunia serta merupakan salah satu produk andalan dari enzim termofilik yang banyak dipakai pada industri pengolahan makanan, detergen dan farmasi (Uyar et al., 2011).

Enzim yang digunakan dalam bidang industri di Indonesia masih diimpor. Padahal Indonesia mampu menghasilkan enzim protease dengan mencari sumber-sumber mikroorganisme penghasil enzim tersebut. Salah satu bakteri penghasil protease, khususnya protease ekstraselular banyak diproduksi oleh spesies Bacillus (Fatoni et al., 2008).

Pada penelitian ini, isolat Bacillus sp. yang digunakan adalah bakteri endofit yang berasal dari tanaman kelapa sawit. Bakteri endofit merupakan bakteri yang dapat perkembang dan tumbuh pada jaringan tumbuhan tanpa merusak inangnya (Pujianto et al., 2010). Isolat yang digunakan pada penelitian ini adalah isolat Bacillus sp. endofit tanaman kelapa sawit yang diisolasi dari bagian akar (BA), pelepah (BP) dan daun (BD) yang merupakan koleksi laboratorium Penyakit Tanaman Jurusan Agroteknologi Fakultas Pertanian, Universitas Riau.

\section{METODOLOGI PENELITIAN} \section{Alat dan Bahan}

Alat-alat yang digunakan dalam penelitian ini adalah Autoclave (All American Model No. 2X), pH meter 210 A orion, Waterbath thermostat (Shibata Scientific Technologamy Ltd.) Spektrofotometer UV-Vis (Thermoscientific Genesys 10S), Vortex mixer (H-VM-300), Shaking incubator (Labtech Model LSI-3016R Serial No. B110221102), Microsentrifuge (Hareous Instrument Biofuge Pico D-37520 Osterode), peralatan standar lainnya yang digunakan dilaboratorium sesuai dengan prosedur kerja.

Bahan-bahan yang digunakan adalah Nutrient broth (Merck), susu skim (Diamond), pepton, $\mathrm{NaCl}$, agar batang, kasein, L-tirosin (Merck), kertas saring (Gf/C Whatman), Whatman syringe filters $0,45 \mu \mathrm{m}$, bovine serum albumin, reagen Folin-Ciocalteau (Merck), serta bahan kimia lainnya sesuai dengan prosedur kerja.

\section{Rancangan Penelitian}

Isolat Bacillus sp. Endofit tanaman kelapa sawit diremajakan terlebih dahulu pada media Nutrient Broth (NB). Kemudian isolat diuji aktivitas proteolitiknya pada media selektif Skim 
Milk Agar (SMA) dan kemudian diproduksi pada media cair Horikoshi.

\section{Inokulasi isolat pada media selektif SMA}

Isolat diuji aktivitas proteolitiknya pada media spesifik Skim Milk Agar (SMA). Media SMA terdiri dari pepton $0,1 \%(\mathrm{w} / \mathrm{v}), \mathrm{NaCl} 0,5 \%$ (w/v), agar batang 2,0\% (w/v) dan susu skim $10 \%(\mathrm{v} / \mathrm{v})(\mathrm{Chu}, 2006)$. Isolat yang sebelumnya telah diinokulasikan pada media NB diambil sebanyak satu ose dan diinokulasikan pada media SMA. Inokulum selanjutnya diinkubasi pada suhu $37^{\circ} \mathrm{C}$ selama \pm 24 jam.

\section{Produksi enzim protease}

Sebanyak satu ose isolat diinokulasikan ke dalam $50 \mathrm{~mL} \mathrm{NB}$ dan diinkubasi dalam Shaker incubator dengan kecepatan $120 \mathrm{rpm}$ pada suhu $37^{\circ} \mathrm{C}$ selama $\pm 24 \mathrm{jam}$. Inokulum tersebut diukur kekeruhan sel bakterinya atau Optical Density (OD) pada panjang gelombang 600nm.

Media produksi Horikoshi yang terdiri dari glukosa $1 \%$, ekstrak ragi $0,5 \%, \mathrm{KH}_{2} \mathrm{PO}_{4} 0,1 \%$, $\mathrm{MgSO}_{4} 0,02 \%, \mathrm{Na}_{2} \mathrm{CO}_{3} 1 \%$ dilarutkan dengan $1 \mathrm{~L}$ akuades lalu diautoklaf dan didiamkan selama selama \pm 24 jam (Tari dkk., 2005). Inokulasi inokulum pada media NB ke media produksi sebanyak $10 \%$ dari media produksi Horikoshi dalam erlenmeyer $100 \mathrm{~mL}$. Jumlah OD untuk setiap inokulum disamakan menjadi 0.1. Media produksi lalu diinkubasi dalam Shaker incubator dengan kecepatan $150 \mathrm{rpm}$ pada suhu $37^{\circ} \mathrm{C}$ selama \pm 24 jam.

\section{Isolasi ekstrak kasar enzim}

Media kultur yang berisi enzim didinginkan pada suhu $10^{\circ} \mathrm{C}$ selama kurang lebih 1 jam. Setelah $1 \mathrm{jam}$, enzim protease yang terdapat dalam media produksi dipisahkan dari sel isolatnya dengan cara disentrifugasi dalam keadaan dingin dengan kecepatan 9500 rpm selama 10 menit. Supernatan disaring dengan filter glass fiber (Whatman GF/C) dan disterilisasi dengan Whatman sterile syringe filter $0,45 \mu \mathrm{m}$. Jika enzim tidak langsung digunakan untuk analisis aktivitas enzim, enzim ditambahkan $\mathrm{NaN}_{3}$ hingga konsentrasi larutan 1 mM ke dalam setiap larutan supernatan.

\section{Penentuan aktivitas enzim protease}

Kasein digunakan sebagai substrat untuk menentukan aktivitas enzim protease dan sebagai standar digunakan larutan tirosin pada berbagai konsentrasi $(5,10,20,40$, dan 50 $\mu \mathrm{g} / \mathrm{ml}$ ) (Cupp dan Enyard, 2008). Tabung uji diisi dengan $5 \mathrm{~mL}$ larutan substrat kasein $0,65 \%$ yang dilarutkan pada bufer pospat $0,05 \mathrm{M} \mathrm{pH}$ 7,5. Tabung uji kemudian diinkubasi selama 5 menit di dalam waterbath dengan suhu $37^{\circ} \mathrm{C}$. Enzim diencerkan terlebih dahulu dengan mencampurkan $1 \mathrm{~mL}$ enzim ditambah $4 \mathrm{~mL}$ larutan bufer, selanjutnya ditambahkan $1 \mathrm{~mL}$ enzim yang sudah diencerkan tadi kedalam tabung dan inkubasi dilanjutkan selama 10 menit.

Tabung untuk kontrol (dari awal 5 menit pertama) diisi dengan $5 \mathrm{~mL}$ larutan substrat kasein $0,65 \%$ yang dilarutkan pada bufer pospat $0,05 \mathrm{M} \mathrm{pH} 7,5$ dan diinkubasi seperti pada sampel tanpa penambahan enzim selama inkubasi 10 menit.

Setelah 10 menit, ke dalam masing-masing tabung ditambahkan $5 \mathrm{~mL}$ reagen trikloroasetat (TCA) lalu larutan dihomogenasi. Kemudian ke dalam tabung kontrol ditambahkan larutan enzim sebanyak $1 \mathrm{~mL}$. Semua tabung diinkubasi kembali pada suhu $37^{\circ} \mathrm{C}$ selama 30 menit. Larutan dalam tabung kontrol dan tabung uji disaring dan diambil filtratnya sebanyak $2 \mathrm{~mL}$. Sebanyak $5 \mathrm{~mL} \mathrm{Na}_{2} \mathrm{CO}_{3}$ dan $1 \mathrm{~mL}$ reagen FolinCiocalteau ditambahkan pada tabung kontrol dan tabung uji. Semua tabung diinkubasi kembali pada suhu $37^{\circ} \mathrm{C}$ selama 30 menit, kemudian diukur absorbansinya pada $660 \mathrm{~nm}$. Pengukuran aktivitas enzim dilakukan masing-masing tiga kali pengulangan untuk setiap sampel. Aktivitas enzim dihitung dengan menggunakan rumus berikut:

$$
\begin{aligned}
& \text { Aktivitas Enzim }= \\
& \begin{array}{l}
\mathrm{X}=\frac{\mu \mathrm{mol} \text { tirosin } \mathrm{uji}-\mu \mathrm{mol} \text { tirosin kontrol }}{\text { Mr tirosin } \mathrm{x} \text { waktu inkubasi } \mathrm{x} \text { volume enzim }} \\
=\mathrm{X} \mu \mathrm{mol} \text { tirosin } / \mathrm{mL} \text { menit } \\
=\mathrm{X} \text { unit } / \mathrm{mL} \text { ekstrak kasar enzim }
\end{array}
\end{aligned}
$$

Satu unit aktivitas enzim protease didefinisikan sebagai banyaknya enzim yang melepaskan $1 \mu \mathrm{mol}$ tirosin permenit. 


\section{HASIL DAN PEMBAHASAN}

Nilai OD dari masing-masing inokulum untuk setiap isolat diukur dengan menggunakan spektrofotometer pada panjang gelombang 600 $\mathrm{nm}$. Inokulum dengan OD yang sama yaitu 0,1 dimasukkan ke media produksi sehingga volume inokulum yang dimasukkan ke dalam media produksi berbeda-beda.

Inokulum untuk masing-masing isolat dibuat agar dapat dihitung jumlah selnya dengan cara menentukan nilai Optical Density (OD) suspensi dalam media cair Nutrient Broth. Perbedaan nilai OD masing-masing isolat disebabkan oleh perbedaan jumlah sel. Semakin keruh suatu suspensi atau semakin besar nilai $\mathrm{OD}$, maka semakin banyak jumlah sel. Berdasarkan Maniatis dkk. (1989), OD $_{660 \mathrm{~nm}}$ denagn nilai 2 setara dengan $1,6 \times 10^{9} \mathrm{sel} / \mathrm{mL}$ kurva standar yang menyatakan hubungan OD dengan jumlah sel per $\mathrm{mL}$.

Inokulum yang telah dimasukkan ke media produksi diinkubasi selama 24 jam dengan suhu $37^{\circ} \mathrm{C}$ dengan kecepatan $150 \mathrm{rpm}$ sehingga diperoleh ekstrak kasar enzim. Ekstrak kasar enzim inilah yang selanjutnya diuji aktivitas proteolitiknya. Aktivitas enzim dinyatakan sebagai jumlah asam amino tirosin yang dilepaskan oleh substrat kasein persatuan waktu. Aktivitas protease Bacillus sp. BD, BA, dan BP dapat dilihat pada Tabel 1.

\section{Tabel 1.}

Nilai aktivitas rata-rata enzim protease Bacillus sp. B1D, B3A, dan B3P dengan waktu produksi 24 jam.

\begin{tabular}{|l|l|}
\hline $\begin{array}{l}\text { Kode } \\
\text { Isolat }\end{array}$ & $\begin{array}{l}\text { Aktivitas Rata-rata Enzim Protease } \mathbf{( x} \\
\left.\mathbf{1 0}^{-3} \mathbf{U} / \mathbf{m L}\right)^{*}\end{array}$ \\
\hline BD & $711,260 \pm 0,735^{\mathrm{a}}$ \\
\hline BA & $708,536 \pm 0,918^{\mathrm{b}}$ \\
\hline BP & $710,027 \pm 0,091^{\text {ab }}$ \\
\hline
\end{tabular}

Catatan:*) Nilai aktivitas enzim rata-rata dari tiga kali pengulangan. Pangkat huruf yang tidak sama menyatakan berbeda secara nyata pada tingkat 5\% $(\mathrm{p}<0.05)$ pada kolom yang sama berdasarkan uji Duncan jarak berganda.

Hasil ANOVA dan uji Duncan jarak berganda untuk aktivitas enzim dari ketiga isolat Bacillus sp. yang dianalisis dari tanaman kelapa sawit (Elaeis quinensis) tertinggi dihasilkan oleh isolat BD sebesar $(711,260 \pm 0,735) \times 10^{-3} \mathrm{U} / \mathrm{mL}$ dan berbeda nyata $(\mathrm{p}<0.05)$ dengan aktivitas enzim pada dua isolat lainnya, yaitu BA sebesar $(708,536 \pm 0,918) \times 10^{-3} \mathrm{U} / \mathrm{mL}$ dan BP sebesar $(710,027 \pm 0,091) \times 10^{-3} \mathrm{U} / \mathrm{mL}$.

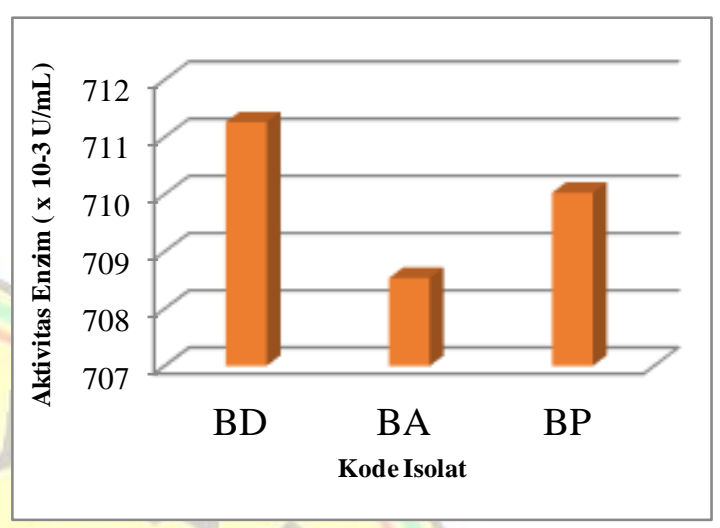

Gambar 1. Grafik aktivitas rata-rata enzim protease.

Media produksi Horikoshi mengandung $\mathrm{MgSO}_{4} .7 \mathrm{H}_{2} \mathrm{O}, \quad \mathrm{KH}_{2} \mathrm{PO}_{4}$, dan $\mathrm{Na}_{2} \mathrm{CO}_{3}$ yang merupakan mineral yang dibutuhkan untuk produksi enzim protease. Logam-logam yang terdapat pada senyawa tersebut merupakan kofaktor bagi aktivitas enzim protease. Fosfat dan sulfat berperan dalam pembentukan asam amino.

Ekstrak kasar enzim diperoleh dengan cara mensentifugasi media produksi dalam keadaan dingin $\left(10^{\circ} \mathrm{C}\right)$ yang bertujuan agar enzim tidak terdenaturasi. Supernatan yang diperoleh kemudian disaring dengan filter glass fiber (Whatman GF/C) agar ekstrak kasar enzim terpisah dengan substrat yang masih terdapat dalam supernatant. Estrak kasar enzim kemudian disterilisasi dengan whatman syringe filter selulosa asetat $0,45 \mu \mathrm{m}$. Sterilisasi ini bertujuan untuk menghilangkan bakteri dan endospora bakteri yang kemungkinan masih terdapat dalam ekstrak kasar enzim.

Penentuan aktivitas protease dari ekstrak kasar enzim protease dilakukan dengan menggunakan substrat kasein $0,65 \%$ dan larutan standar tirosin. Enzim protease yang diuji akan memecah kasein sehingga menyebabkan asam amino tirosin dilepas dengan asam amino lainnya dan peptida. Reagen Folin kemudian bereaksi dengan asam amino tirosin bebas menghasilkan kromofor berwarna biru. Warna 
biru inilah yang dihitung nilai absorbansinya dengan menggunakan spektrofotometer pada panjang gelombang $660 \mathrm{~nm}$.

Nilai aktivitas yang diperoleh pada penelitian ini lebih tinggi dibandingkan nilai aktivitas enzim protease Bacillus sp. B2 asal tanaman sawi yang memiliki nilai aktivitas $(15,2885 \pm 0,0030) \times 10^{-3} \mathrm{U} / \mathrm{mL}$ pada media Horikoshi pada waktu produksi 24 jam (Yuniati, 2015). Hal ini dapat disebabkan oleh konsentrasi protein yang terdapat dalam tanaman kelapa sawit lebih banyak dibandingan konsentrasi pada tanaman sawi. Patel dkk. (2004) melaporkan aktivitas enzim protease Bacillus sp. Vel memiliki nilai aktivitas protease maksimum sebesar $397 \mathrm{U} / \mathrm{mL}$ pada media gelatin cair dan Nilegaonkar dk. (2006) melaporkan bahwa enzim protease Bacillus cereus MCM B-326 yang diisolasi dari kulit kerbau memiliki aktivitas maksimum sebesar 126,87 U/mL. Tingginya aktivitas yang diperoleh pada penelitian ini diperkirakan disebabkan oleh pemilihan media produksi yang sesuai. Komposisi media produksi enzim sangat mempengaruhi aktivitas enzim yang dihasilkan. Menurut Meryandini dk. (2009), perbedaan pertumbuhan antara isolat bakteri berdasarkan atas kemampuannya dalam mendegradasi substrat dan komposisi yang ditambahkan dalam media. Menurut penelitian Banarjee dkk. (1999), penambahan logam $\mathrm{Mg}^{2+} 1 \mathrm{mM}$ dapat menurunkan aktivitas enzim protease Bacillus brevis sebesar $9 \%$, sedangkan Nascimento dkk. (2004) melaporkan bahwa penambahan logam $\mathrm{Mg}^{2+}$ juga menurunkan aktivitas enzim protease Bacillus sp. 39\%. Pada penelitian ini, nilai aktivitas dan aktivitas spesifik enzim terbesar terdapat pada isolat Bacillus sp. BD (daun), hal ini dapat disebabkan oleh banyaknya kandungan protein pada bagian daun tumbuhan tanaman kelapa sawit. Tumbuhan menyerap unsur-unsur hara dalam tanah melalui akar dan disalurkan keseluruh bagian tanaman sampai ke daun sehingga tumbuhan membentuk protein dan melakukan perombakan (proses katabolisme) (Zulhijah, 2012).

\section{KESIMPULAN}

Berdasarkan hasil penelitian yang telah dilakukan, maka dapat disimpulkan bahwa isolat Bacillus sp. BD, BA, dan BP memiliki nilai aktivitas enzim secara berturut adalah $(711,260$ $\pm 0,735) \times 10^{-3} \mathrm{U} / \mathrm{mL},(708,536 \pm 0,918) \times 10^{-3}$ $\mathrm{U} / \mathrm{mL}$ dan $(710,027 \pm 0,091) \times 10^{-3} \mathrm{U} / \mathrm{mL}$ pada waktu produksi 24 jam.

\section{DAFTAR PUSTAKA}

Benarjee, U.C., Sani, R.K., Azmi, W., dan Soni, R. 1999. Thermostable alkaline protease from Bacillus brevis and its characterization as a laundry detergent additive. Process Biochemistry. 35: 213219.

Chu, W.H. 2006. Optimization of Extracellular Alkaline Protease Production From Species of Bacillus. J Ind Microbiol Biotechnol. 34: 241-245.

Cupp, C dan Enyard. 2008. Sigma's Nonspecific Protease Activity Assay - Casein as a Substrate. Journal of Visualized Experiments. 19: 899-904.

Fatoni, Amin., Zusfahair., dan Lestari, Puji. 2008. Isolasi dan Karakterisasi Protease Ekstraseluler dari Bakteri dalam Limbah Cair Tahu. Jurnal Natur Indonesia. 10: 8388.

Meryandini, A., Widosari, W., Maranatha, B., Sunarti, T.C., Rachmania, N., dan Satria, H. 2009. Isolat bakteri selulolitik dan karakterisasi enzimnya. Makara Sains. 13: 33-38.

Nascimento, W.C.A., dan Martins, M.L.L. 2004. Production and properties of an extracellular protease from thermophilic Bacillus sp. Brazillian Journal of Microbiology. 35: 91-96.

Nilegaonkar, S.S., Zambare, V.P., Kanekar, P.P., Dhakephalkar, P.K., dan Saranik, S.S. 2006. Production and partial characterization of dehairing protease from Bacillus cereus MCM B-326. Bioresource Technology. 98: 1238-1245.

Patel, R., Dodia, M., dan Singh, S.P. 2004. Extracellular alkaline protease from a newly isolated haloalkaliphilic Bacillus sp.: 
production and optimization. Process Biochemistry. 40: 3569-3575.

Tari, C., Genckal, H., dan Tokatl, F. 2005. Optimization of a Growth Medium Using a Statistical Approach for The Production of an Alkaline Protease From a Newly Isolated Bacillus sp. L21. Process Biochemistry. 41: 659-665.

Uyar, Fikret., Porsuk, Ilknur., Kizil, Goksel., dan Yilmaz, Ebru Ince. 2011. Optimal Conditions for Production of Extracellular
Protease from Newly Isolated Bacillus cereus Strain CA15. Eurasian Journal of Biosciences. 5: 1-9.

Yuniati, Rani. 2015. Uji Aktivitas Enzim Protease dari Isolat Bacillus sp. Galur Lokal Riau. Skripsi. FMIPA, UR. Pekanbaru.

Zulhijah, S. 2012. Protein pada tanaman. http://dzoelhizz.blogspot.com. Diakses pada 1 September 2015.

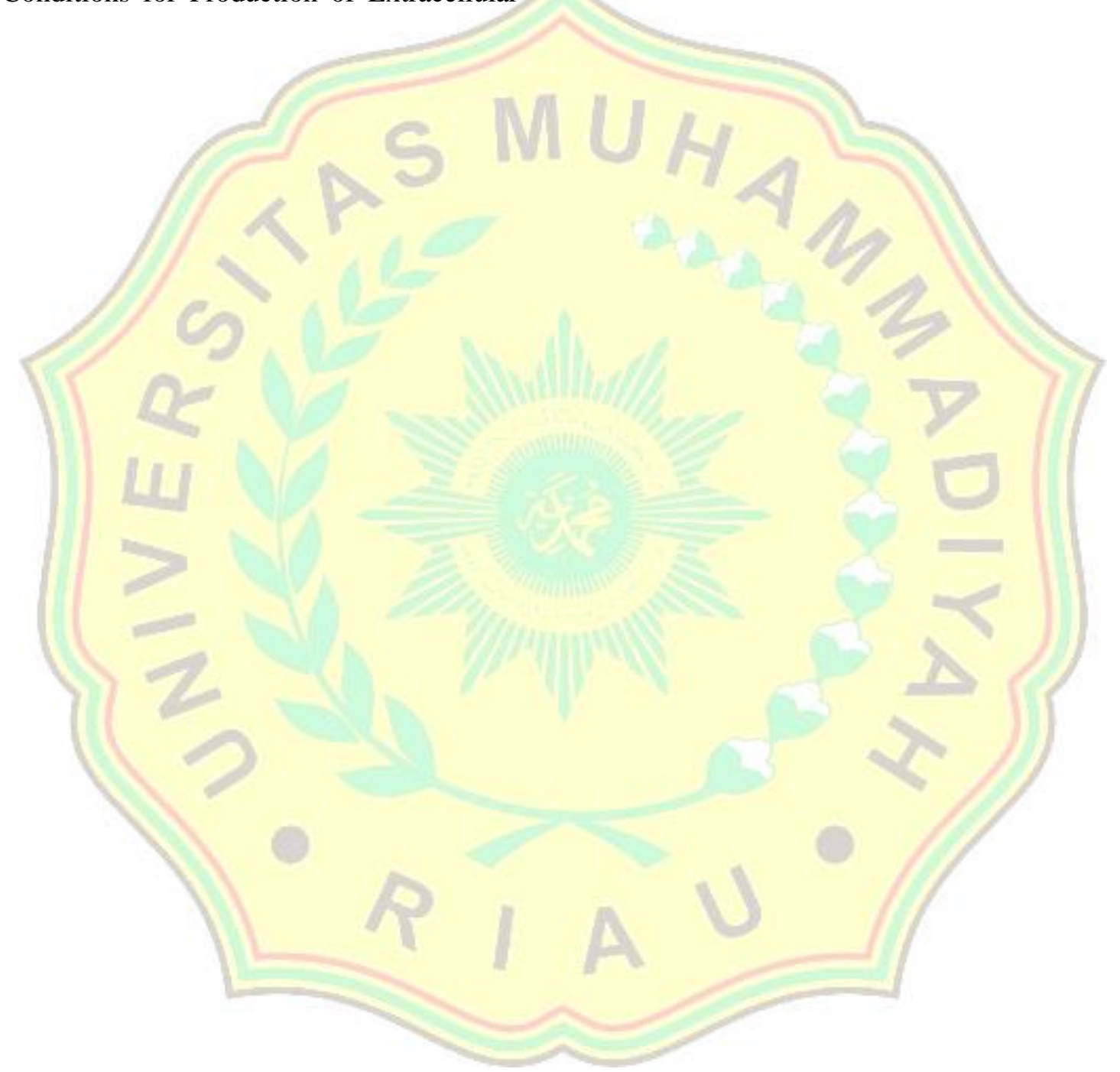

